\title{
Correction to: Extreme rainfall in Mediterranean France during the fall: added value of the CNRM-AROME Convection-Permitting Regional Climate Model
}

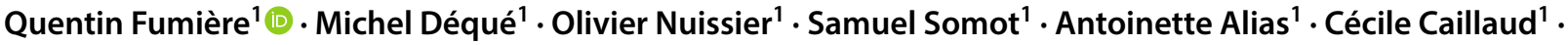 \\ Olivier Laurantin ${ }^{2} \cdot$ Yann Seity ${ }^{1}$
}

Published online: 30 September 2019

(c) The Author(s) 2019

\section{Correction to: Climate Dynamics \\ https://doi.org/10.1007/s00382-019-04898-8}

Unfortunately, the article "Extreme rainfall in Mediterranean France during the fall: added value of the CNRM-AROME Convection-Permitting Regional Climate Model", written by Quentin Fumière was originally published electronically on the publisher's internet portal (currently SpringerLink) on 24 July 2019 without open access with incorrect copyright holder as "C Springer-Verlag GmbH Germany, part of Springer Nature 2019”.

The article is now corrected and the copyright holder of the article is changed on [25 September 2019] to (C) The Author(s) 2019 and the article is forthwith distributed under the terms of the Creative Commons Attribution 4.0 International License (http://creativecommons.org/licenses/by/4.0/), which permits use, duplication, adaptation, distribution and reproduction in any medium or format, as long as you give appropriate credit to the original author(s) and the source, provide a link to the Creative Commons license and indicate if changes were made.

The original article was corrected.

Open Access This article is distributed under the terms of the Creative Commons Attribution 4.0 International License (http://creativecommons.org/licenses/by/4.0/), which permits unrestricted use, distribution, and reproduction in any medium, provided you give appropriate credit to the original author(s) and the source, provide a link to the Creative Commons license, and indicate if changes were made.

Publisher's Note Springer Nature remains neutral with regard to jurisdictional claims in published maps and institutional affiliations.
The original article can be found online at https://doi.org/10.1007/ s00382-019-04898-8.

Quentin Fumière

quentin.fumiere@meteo.fr

1 CNRM, CNRS, Université de Toulouse, Météo-France,

Toulouse, France

2 DSO, Météo-France, Toulouse, France 